\title{
RESEARCH
}

Open Access

\section{Longitudinal follow-up of autophagy and inflammation in brain of APPswePS1dE9 transgenic mice}

Arnaud François ${ }^{1 *}$, Agnès Rioux Bilann ${ }^{1}$, Nathalie Quellard ${ }^{2}$, Béatrice Fernandez ${ }^{2}$, Thierry Janet ${ }^{1}$, Damien Chassaing ${ }^{1}$, Marc Paccalin ${ }^{1,3,4,5}$, Faraj Terro ${ }^{1,6,7 \dagger}$ and Guylène Page ${ }^{1 \dagger}$

\begin{abstract}
Background: In recent years, studies have sought to understand the mechanisms involved in the alteration of autophagic flux in Alzheimer's disease (AD). Alongside the recent description of the impairment of lysosomal acidification, we wanted to study the relationships between inflammation and autophagy, two physiological components deregulated in AD. Therefore, a longitudinal study was performed in APPswePS1dE9 transgenic mice at three, six and twelve months of age.
\end{abstract}

Methods: Autophagic markers (Beclin-1, p62 and LC3) and the activation of mammalian Target of Rapamycin (mTOR) signaling pathway were quantified by western blot. Cytokine levels (IL-1 $\beta$, TNF-a and IL-6) were measured by ELISA. Transmission electron microscopy was performed to detect autophagic vacuoles. Mann-Whitney tests were used to compare wild-type (WT) versus APPswePS1dE9 mice. Longitudinal changes in parameters were analyzed with a Kruskal-Wallis test followed by a post-hoc Dunn's test. Correlation between two parameters was assessed using a Spearman test.

Results: Compared to 12-month old WT mice, 12-month old APPswePS1dE9 mice had higher levels of IL-1 $\beta$ and TNF-a, a greater inhibition of the mTOR signaling pathway and lower levels of Beclin-1 expression both in cortex and hippocampus. Regarding the relationship of the various parameters in 12-month old APPswePS1dE9 mice, Beclin-1 rates were positively correlated with IL-1 $\beta$ and TNF-a levels. And, on the contrary, TNF-a levels were inversely correlated with the levels of mTOR activation. Altogether, these results suggest that inflammation could induce autophagy in APPswePS1dE9 mice. However, these transgenic mice displayed a large accumulation of autophagic vesicles within dystrophic neurons in cortex and hippocampus, indicating a terminal failure in the autophagic process.

Conclusions: This first demonstration of relationships between inflammation and autophagy in in vivo models of AD should be taken into account in new therapeutic strategies to prevent inflammation and/or stimulate autophagy in advanced neurodegenerative process such as AD.

Keywords: Alzheimer, Beclin-1, IL-1 $\beta$, TNF- $\alpha$, Transgenic mouse model

\footnotetext{
* Correspondence: arnaudfrancois85@gmail.com

${ }^{\dagger}$ Equal contributors

'EA3808 molecular Targets and Therapeutic of Alzheimer's disease, University of Poitiers, 1 Rue Georges Bonnet, TSA 5110686073 Poitiers, Cedex 9, France Full list of author information is available at the end of the article
} 


\section{Introduction}

Alzheimer's disease (AD) is a progressive dementia with atrophy, senile plaques of fibrillogenic beta-amyloid (A $\beta)$ and intraneuronal neurofibrillary tangles with hyperphosphorylated tau. In 1988, it was discovered that microglia around $A \beta$ deposits expressed major histocompatibility complex type II, a marker for activated immune cells [1-4]. However, the notion that the CNS is an immunologically privileged organ is questioned and microglia are generally recognized as the brain's resident players in innate immune/inflammatory responses in AD. Like microglia, reactive astrocytes encircle $A \beta$ deposits in a manner reminiscent of glial scarring [5-7]. In addition, many molecular mediators are involved in the inflammatory response in $\mathrm{AD}$, including complement factors, cytokines, chemokines, pattern recognition receptors, scavenger receptors, cyclooxygenases and reactive oxygen species [8-11]. Several data from literature are in favor of a deleterious role of inflammation, in particular the activation of the inflammasome [10,12-15], but more research is needed to better understand its role according to the stage of the disease and the many failures of anti-inflammatory therapies in patients with AD.

It is known that peripheral inflammation plays a role in cell proteolysis; in particular, molecular relationships were identified with macroautophagy (called autophagy) which degrades long-lived proteins and organelles [16-21]. Autophagy has an anti-inflammatory function as demonstrated in a mouse model of Crohn's disease [22] and many studies have shown that autophagy targets ubiquitinated aggregated inflammasome components for destruction [23-26]. Autophagy may have a protective role against the development of a number of neurodegenerative diseases $[27,28]$. Autophagy deregulation was initially linked to $\mathrm{AD}$ when electron microscopy studies revealed the accumulation of autophagic vacuoles in the brains of $\mathrm{AD}$ patients $[29,30]$. Compelling evidence indicates that $A \beta$ is generated in autophagic vacuoles during autophagy, suggesting that autophagy may exacerbate AD pathogenesis by increasing $A \beta$ levels [31-33]. Furthermore, clearance of autophagic vacuoles is impaired in AD brains [34] and one probable contributor to autophagy deficiency in $\mathrm{AD}$ appears to be Beclin-1, whose expression is strongly reduced in the brains of $\mathrm{AD}$ patients to levels that would be predicted to impair autophagosome synthesis $[35,36]$. The relationships between autophagy and inflammation in $\mathrm{AD}$ have not yet been explored in vivo. This present study aims to track key inflammatory cytokine actors (IL-1 $\beta$, TNF- $\alpha$ and IL-6) and autophagy markers (Beclin-1, p62 and microtubule-associated protein 1/light chain 3 (LC3)) in APPswePS1dE9 transgenic mice. These mice are used extensively in research and have a significant inflammatory response at 12 months. However, their autophagic status has never been followed over time.

\section{Materials and methods Chemical products}

Sodium fluoride $(\mathrm{NaF})$, phenylmethylsulfonyl fluoride (PMSF), protease and phosphatase inhibitor cocktails, dithiothreitol (DTT), paraformaldehyde (PFA) and all reagent-grade chemicals for buffers were purchased from Sigma (St Quentin Fallavier, France); sodium pentobarbital from CEVA, Animal Health (Libourne, France); NuPAGE ${ }^{\circ}$ LDS 4X Sample Buffer, NuPAGE ${ }^{\oplus}$ Sample Reducing Agent (10X), Novex 4 to $20 \%$ Tris-Glycine Mini gels, NuPAGE ${ }^{\circ}$ 3 to $8 \%$ Tris-Acetate gels, Novex ${ }^{\circ}$ Tris-Glycine SDS Running Buffer and NuPAGE ${ }^{\bullet}$ Tris-Acetate SDS Running Buffer, NuPAGE ${ }^{\oplus}$ Antioxidant, Seeblue ${ }^{\circ}$ Plus 2 pre-stained standard, iBlot ${ }^{\circ}$ Gel Transfer Device (EU), Quant-it ${ }^{\circ}$ protein assay from Gibco-Invitrogen (Fisher Bioblock Scientific distributor, Illkirch, France); 4X Laemmli Sample Buffer, 4 to $15 \%$ mini-PROTEAN ${ }^{\circ}$ TGX $^{\mathrm{tm}}$ gels, Tris-Glycine Running Buffer and Trans-Blot ${ }^{\circ}$ Turbo $^{\text {Ts }}$ Transfer System from Bio-Rad (Marnes-la-Coquette, France).

For western blot, primary antibodies and secondary anti-rabbit IgG antibody conjugated with horseradish peroxidase (HRP) were purchased from Cell Signalling (Ozyme, Saint-Quentin-en-Yvelines, France) except sequestosome 1 (p62/SQMT1) from MBL (CliniSciences distributor, Nanterre, France), anti- $\beta$ tubulin from Sigma (St Quentin Fallavier, France), HRP-conjugated anti-mouse IgG from Amersham Biosciences (Orsay, France), IgGand protease-free BSA from Jackson ImmunoResearch Europe Ltd (Interchim distributor, Montluçon, France). Molecular biology reagents were obtained from Promega (Charbonnières, France).

\section{Animals}

Male hemizygote B6C3-Tg (APPswe, PS1dE9)85Dbo (stock \#004462) and female wild-type (WT) mice (B6C3F1, stock \#10010) were obtained from Jackson Laboratories (Bar Harbor, ME USA) and bred to create colonies of APPswePS1dE9 and WT mice. As described in the website of Jackson Laboratories, two expression plasmids (Mo/HuAPP695swe and PS1-dE9) were designed to each be controlled by independent mouse prion protein $(\operatorname{PrP})$ promoter elements, directing transgene expression predominantly to central nervous system (CNS) neurons. The Mo/HuAPP695swe transgene expresses a 'humanized' mouse amyloid beta (A4) precursor protein gene modified at three amino acids to reflect the human residues and further modified to contain the K595N/M596L mutations linked to familial Alzheimer's disease (FAD). The PS1dE9 transgene expresses a mutant human presenilin 1 carrying the exon-9-deleted variant (PSEN1dE9) associated with FAD. Occasional deposits can be found in mice as young as six months of age and plaques are abundant in hippocampus and cortex by nine months of age. Furthermore, in this APPswePS1dE9 mouse model of AD, 
amyloid plaques and its associated inflammatory response develop at early stage of the life and progressively increase with age [36,37].

Mice derived from crosses of 12 breeders. At weaning, all mice were tattooed (ISO Tiny chip, Biolog-id, Bernay, France), genotyped by PCR analysis of tail biopsies according to the manufacturer's recommended protocol (KAPA Mouse Genotyping HotStart Kit, CliniSciences, Nanterre, France).

The use of animals for this study was approved by the Ethical and Animal Care Committee at 'La direction départementale de la protection de la population (DDPP)' (registration number: 06.12). An agreement was obtained from The High Council of Biotechnology for transgenic animals in 2010 (5418 number agreement). All animal care and experimental procedures conformed with the French Décret number 2013-118, 1 February 2013 NOR: AGRG1231951D in accordance to European Community guidelines (directive 2010/63/UE for the Care and Use of Laboratory Animals). All efforts were made to minimize animal suffering as well as the number of animals used. The animals were housed in a conventional state under adequate temperature $\left(23 \pm 3^{\circ} \mathrm{C}\right)$ and relative humidity $(55 \pm 5 \%)$ control with a $12 / 12$ hour reversed light/dark cycle, and provided with food and water ad libitum.

\section{Brain tissue preparation for biochemical analysis}

At 3, 6 and 12 months of age, mice were transcardially perfused with PBS $\left(154 \mathrm{mM} \mathrm{NaCl}, 1.54 \mathrm{mM} \mathrm{KH_{2 }} \mathrm{PO}_{4}\right.$, $2.7 \mathrm{mM} \mathrm{Na} 2 \mathrm{HPO}_{4} .7 \mathrm{H}_{2} \mathrm{O}, \mathrm{pH}$ 7.2) after deep anesthesia with pentobarbital $(80 \mathrm{mg} / \mathrm{kg}$, intraperitoneally (ip)). Brains were rapidly removed and dissected on ice. Cortex and hippocampus were homogenized using 10 up-and-down strokes of a prechilled Teflon-glass homogenizer in 20 volumes of lysis buffer $(25 \mathrm{mM}$ Tris- $\mathrm{HCl}, 150 \mathrm{mM} \mathrm{NaCl}$, $1 \mathrm{mM}$ EDTA, pH 7.4) and supplemented with $50 \mathrm{mM}$ NaF, $1 \mathrm{mM}$ PMSF, protease and phosphatase inhibitor cocktails $(50 \mu \mathrm{L} / \mathrm{g}$ of tissue and $10 \mu \mathrm{L} / \mathrm{mL}$ of lysis buffer, respectively). Lysates were sonicated and centrifuged at $15,000 \mathrm{~g}$ for 15 minutes at $4^{\circ} \mathrm{C}$. The resulting supernatants were collected for Quant-it ${ }^{\circ}$ protein assay according to the manufacturer's protocol. Samples were stored at $-20^{\circ} \mathrm{C}$ until ELISA and immunoblotting described below. For q-PCR, a piece (10 mg of tissue) of cortex and hippocampus was immediately homogenized in RNA lysis buffer available in the kit from Promega by using sterile 25 -gauge needle and syringe. These samples were stored at $-80^{\circ} \mathrm{C}$ until RNA extraction.

\section{TaqMan real-time PCR}

Total RNA was isolated from cortex and hippocampus by using SV Total RNA Isolation System according to the manufacturer's instructions (Promega, Charbonnieres, France). Concentration of total RNA was measured by using a nanodrop (Nanodrop 2000 spectrophotometer, ThermoScientific (Villebon sur Yvette, France). Total RNA isolate (500 ng) was converted into first strand cDNA using ImProm- $-\mathrm{II}^{\mathrm{Tm}}$ Reverse Transcription System (Promega, Charbonnieres, France) .

The TaqMan probes and primers were designed according to the sequence of murine p62, LC3, Beclin-1 and S6 ribosomal protein genes using the Primer Express software version 2.0 (ABI Applied Biosystems, Foster City, CA, USA). Primers p62-F (5'-CTGCACAGGGAACACA GCAA-3') and p62-R (5' GCCAGCGGCTATGAGAGA AG-3'), LC3-F (5' '-TCGCCGACCGCTGTAAG-3') and LC3-R (5' -CTCGATGATCACCGGGATCT-3'), Beclin-F (5' -CTGCACAGGGAACACAGCAA- ${ }^{\prime}$ ) and Beclin-R (5'-GCCAGCGGCTATGAGAGAAG-3') and S6-F (5'-A AGTCGGGCCTCTTTTTCGT-3') and S6-R (5' GGGAA GGAGATGTTCAGCTTCA-3') were designed to yield respectively a $79 \mathrm{bp}, 71 \mathrm{bp}, 146 \mathrm{bp}$ and $73 \mathrm{bp}$ fragments of the p62, LC3, Beclin-1 and S6 ribosomal protein genes. The TaqMan probes p62-P $\left(5^{\prime}\right.$-TCCCAACCC CTTTGGCCACCTCT-3'), LC3-P (5'-TCCGCGACC AGCACCCCAG-3'), Beclin-P (5' - CCTTCCACATC TGGCACAGCGGA-3'); S6-P (5' -CCTCCCAGGCGC TCGGCTG-3'); contained 6-carboxy-fluorescein (FAM) reporter dye at the $5^{\prime}$ end and 6-carboxytetramethylrhodamine (TAMRA) fluorescent quencher at the $3^{\prime}$ end. Primers and probes were commercially synthesized by Eurogentec (Angers, France). TaqMan real-time PCR was performed in an ABI 7500 real-time PCR system (Applied Biosystems, Foster City, CA, USA). Amplification reaction contained 2X TaqMan Universal Master Mix (Applied, Villebon-sur-Yvette, France), $900 \mathrm{nM}$ of each primer (p62-F and p62-R or LC3-F and LC3-R or Beclin1-F and Beclin-R), $900 \mathrm{nM}$ of probe and cDNA template and nuclease-free water to a final volume of $13 \mu \mathrm{L}$. The thermal profile consisted of $50^{\circ} \mathrm{C}$ for 2 minutes, followed by $95^{\circ} \mathrm{C}$ for 10 minutes and 40 cycles of $95^{\circ} \mathrm{C}$ for 15 seconds and $59^{\circ} \mathrm{C}$ for 1 minute. Fluorescence was measured once per cycle at the end of the $59^{\circ} \mathrm{C}$ segment.

The standard curve was generated using 10-fold serial dilutions with $\mathrm{ddH}_{2} \mathrm{O}$ from $10^{-1}$ to $10^{-6} \mathrm{cDNA}$ synthesized from RNA of lipopolysaccharide (LPS)-treated mouse spleen (positive control). The PCR conditions for this standard curve were adopted to perform the further reactions to estimate transcriptional expression of p62, LC3 and Beclin-1 by TaqMan real-time PCR assay. For each gene and structure, results were normalized relatively to mean of WT mice.

\section{ELISA}

Commercially available ELISA kits were used for assessing IL-1 $\beta$ (sensitivity: $16 \mathrm{pg} / \mathrm{mL}$ ) TNF- $\alpha$ (sensitivity: $4 \mathrm{pg} / \mathrm{mL}$ ) and IL-6 (sensitivity: $2 \mathrm{pg} / \mathrm{mL}$ ) according to the manufacturers' instructions (BioLegend, Ozyme, 
Saint-Quentin-en-Yvelines, France). The range of analysis was between 31.3 to $2,000 \mathrm{pg} / \mathrm{mL}$ for IL- $1 \beta$ and 7.8 to $500 \mathrm{pg} / \mathrm{mL}$ for TNF- $\alpha$ and IL-6. Homogenates from brain tissue $(50 \mathrm{mg}$ of tissue $/ \mathrm{mL}$ ) were added in each well of pre-coated plates and all steps were performed at room temperature (RT). The enzymatic reaction was stopped after 15 minutes incubation with tetramethylbenzidine (TMB) substrate by adding $2 \mathrm{~N} \mathrm{H}_{2} \mathrm{SO}_{4}$ and the optical density (OD) was read at $450 \mathrm{~nm}$ within 30 minutes, using the Multiskan ${ }^{\circledast}$ spectrum spectrophotometer (ThermoScientific, Villebon sur Yvette, France). The cytokine levels were then calculated by plotting the OD of each sample against the standard curve. The intra- and inter-assay reproducibility was $>90 \%$. OD values obtained for duplicates that differed from the mean by greater than $10 \%$ were not considered for further analysis. For convenience, all results are expressed in $\mathrm{pg} / \mathrm{mg}$ protein.

\section{Immunoblottings}

Samples (40 $\mu$ g proteins) were prepared for electrophoresis by adding NuPAGE 4 X LDS Sample Buffer and NuPAGE ${ }^{\oplus}$ Sample Reducing Agent (10X). Samples were then heated up $100^{\circ} \mathrm{C}$ for 5 minutes, loaded into Novex ${ }^{\circ}$ 4 to $20 \%$ Tris-Glycine mini Gels, run at $150 \mathrm{~V}$ for $60 \mathrm{mi}-$ nutes in Novex ${ }^{-}$Tris-Glycine SDS Running Buffer and in NuPAGE 3 to $8 \%$ Tris-Acetate Gels, run at $125 \mathrm{~V}$ for 120 minutes in NuPAGE ${ }^{\circledR}$ Tris-Acetate SDS Running Buffer containing NuPAGE antioxidant. Gels were transferred to nitrocellulose membranes using the iBlot ${ }^{\ominus}$ Dry blotting system set to program $20 \mathrm{~V}$ for 7 minutes. For LC3 analysis, we used Trans-Blot ${ }^{\circ}$ Turbo $^{\mathrm{Tm}}$ Transfer System (25 V, 3 minutes for $0.2 \mu \mathrm{m}$ nitrocellulose MISI format) after protein gel electrophoresis of samples prepared in 4X Laemmli Sample Buffer and loaded into 4 to $15 \%$ mini-PROTEAN ${ }^{-}$TGX $^{\mathrm{Tm}}$ gels with Tris-Glycine SDS Running Buffer.

Membranes were washed for 10 minutes in Tris-buffered saline/Tween (TBST: $20 \mathrm{mM}$ Tris- $\mathrm{HCl}, 150 \mathrm{mM} \mathrm{NaCl}$, $\mathrm{pH} 7.5,0.05 \%$ Tween 20) and not specific antigenic sites were blocked for 2 hours in TBST containing 5\% BSA.

Blots were incubated with primary antibody in blocking buffer overnight at $4^{\circ} \mathrm{C}$. Antibodies used were rabbit anti- $\mathrm{P}_{\mathrm{S} 2448}-\mathrm{mTOR}$, anti-total mTOR, anti- $\mathrm{P}_{\mathrm{T} 389}-\mathrm{p} 70 \mathrm{~S} 6 \mathrm{~K}$, anti-total p70S6K, anti-Beclin-1, anti-p62, anti-LC3, all at 1:500 dilution factor. Membranes were washed twice with TBST and then incubated with the HRP-conjugated secondary antibody anti-rabbit IgG $(1: 1,000)$, during 1 hour at RT. Membranes were washed again and exposed to the chemiluminescence Luminata Forte Western HRP Substrate (Millipore, Saint-Quentin-en-Yvelines, France) followed by signal capture with the Gbox system (GeneSnap software, Syngene, Ozyme distributor, Saint-Quentinen-Yvelines, France). After 2 washes in TBST, membranes were probed with mouse antibody against $\beta$-tubulin $(1: 10,000)$ overnight at $4^{\circ} \mathrm{C}$. They were then washed with TBST, incubated with HRP-conjugated secondary antibody anti-mouse $(1: 1,000)$ for 1 hour, exposed to the chemiluminescence Luminata classico substrate (Millipore, Saint-Quentin-en-Yvelines, France) and signals were captured. Automatic image analysis software is supplied with Gene Tools (Syngene, Ozyme distributor, SaintQuentin-en-Yvelines, France). Protein $/ \beta$-tubulin ratios were calculated and shown in the corresponding figures. Phospho-protein/total protein ratios were calculated to evaluate rates of protein activation.

\section{Transmission electron microscopy (TEM)}

For brain TEM, four mice were transcardially perfused with PBS followed by 4\% PFA perfusion after deep anesthesia with pentobarbital $(80 \mathrm{mg} / \mathrm{kg}$, ip). Brains were rapidly removed on ice and thin sagittal sections were isolated and fixed with $3 \%$ glutaraldehyde in PBS (0.1 M; $\mathrm{pH}=7.4)$ for 2 hours at $4^{\circ} \mathrm{C}$. Samples $\left(2 \mathrm{~mm}^{3}\right.$ of tissue in cortex and hippocampus) were then washed three times $(3 \times 10$ minutes $)$ in PBS before being post-fixed in $1 \%$ osmium tetroxide in PBS for 1 hour at $4^{\circ} \mathrm{C}$, processed through a graded acetone series, embedded in Araldite (Fluka, Buchs, Switzerland) and polymerized overnight at $60^{\circ} \mathrm{C}$. Thin sections $(60 \mathrm{~nm})$ were cut with a diamond knife on Reichert Ultracut (Leica, Nanterre, France) S, recovered on $\mathrm{Cu}$ grids and contrasted with uranyl acetate $(4 \%)$ and lead citrate and were observed under a JEOL 1010 transmission electron microscope (Jeol Ltd, Tokyo, Japan).

\section{Statistical analysis}

For biochemical analysis, results are expressed as means \pm SEM. To compare quantitative variables between WT mice and APPswePS1dE9 mice, Mann-Whitney tests were used. Comparisons between the three classes of age in both groups of mice were performed using a Kruskal-Wallis test followed by a post-hoc Dunn's test. Correlations between two quantitative parameters in APPswePS1dE9 mice were estimated by Spearman tests (GraphPad Instat, GraphPad Software, San Diego, CA, USA). The level of significance was $P<0.05$.

\section{Results}

\section{Longitudinal monitoring of cytokines in the brain of APPswePS1dE9 mice}

IL-1 $\beta$ levels in APPswePS1dE9 mice were significantly higher in cortex (3.1-fold) and hippocampus (4.5-fold) than those of WT mice only at 12 months of age. Furthermore, 12 -month old APPswePS1dE9 mice produced more IL-1 $\beta$ than 3-month old APPswePS1dE9 mice (6.8-fold in cortex, 6-fold in hippocampus) and 6-month old APPswePS1dE9 mice (3.25-fold in cortex and 3.9-fold in hippocampus), 
(Figure 1A and C). TNF- $\alpha$ levels were higher in 12-month old APPswePS1dE9 mice than in respective WT mice (2.3-fold) in hippocampus only (Figure $1 \mathrm{~B}$ and D). For IL-6 levels, no difference between the two groups of mice at 12 months of age was observed in both brain areas (cortex: $2.13 \pm 0.33$ and $2.94 \pm 0.59 \mathrm{pg} / \mathrm{mg}$ protein for APPswePS1dE9 and WT mice, respectively; hippocampus: $3.30 \pm 0.37$ and $2.82 \pm 0.49 \mathrm{pg} / \mathrm{mg}$ protein for APPswePS1dE9 and WT mice, respectively).

\section{Changes in activation of the mTOR signaling pathway}

mTOR activation leads to phosphorylation of various substrates, in particular p70S6K at T389, a ribosomal S6 kinase involved in ribogenesis [38,39]. Furthermore, it is also well known that autophagy is inhibited by the activation of the mTOR signaling [40].

In APPswePS1dE9 mice, the activation of mTOR and p70S6K decreased with age (Figure 2). Indeed, significant decreases were observed in 12-month old APPswePS1dE9 mice compared to WT mice $(56 \%$ and $63.7 \%$ in cortex, $41.6 \%$ and $53.2 \%$ in hippocampus for mTOR and p70S6K, respectively). Furthermore, the activation of mTOR and p70S6K in twelve-month old APPswePS1dE9 mice was significantly different compared to transgenic mice at three and six months of age (Figure 2). Interestingly, the mTOR signaling pathway impairment was observed from 6-month old APPswePS1dE9 mice in hippocampus (decrease in $58.8 \%$ and $36 \%$ for mTOR and p70S6K compared to WT mice, respectively) and mTOR activation in 12-month old APPswePS1dE9 mice was significantly different compared to 3-month old APPswePS1dE9 mice (Figure $2 \mathrm{C}$ and $\mathrm{D}$ ).

\section{Longitudinal monitoring of autophagy markers in the brain of APPswePS1dE9 mice}

To explore autophagy in both groups of mice, immunoblottings of Beclin-1, p62, LC3-I and LC3-II were performed. The levels of expression of Beclin-1, which is a key component in the initiation of autophagosome formation [41], decreased in 12-month old APPswePS1dE9 mice (57\% and $36.8 \%$ in cortex and hippocampus compared to 12-month old WT mice, respectively). Regarding autophagy
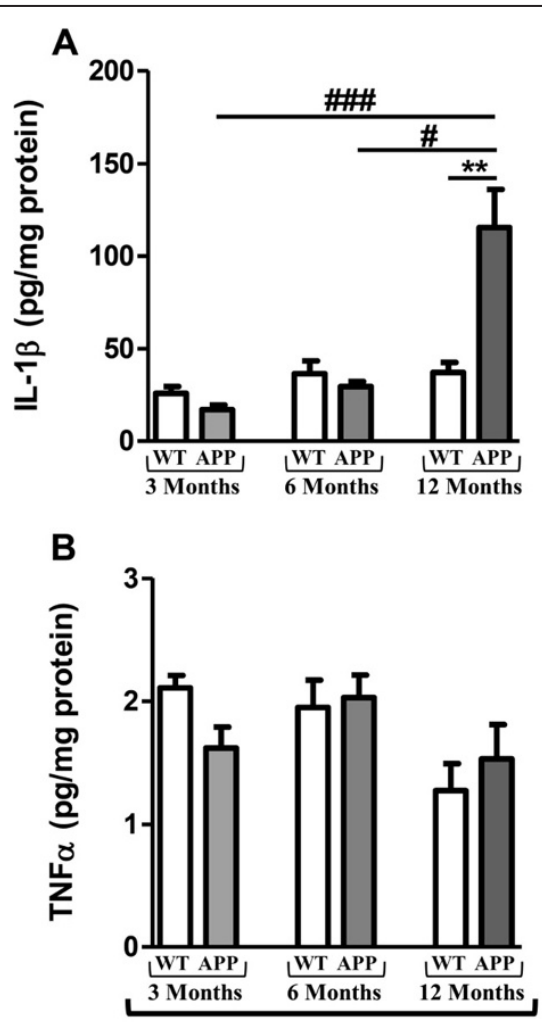

Cortex
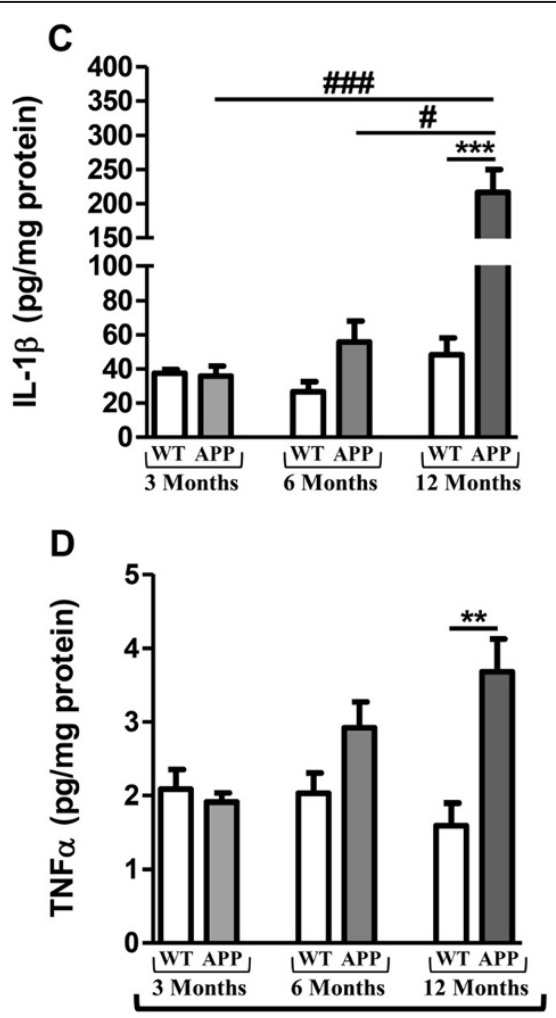

Hippocampus

Figure 1 Longitudinal monitoring of cytokines in the brain of APPswePS1dE9 mice. IL1- $\beta$ and TNF-a levels were measured by ELISA in cortex (A and B) and hippocampus (C and D) of APPswePS1dE9 (APP) and wild-type mice (WT) at three, six and twelve months of age. Cytokine levels were expressed in $\mathrm{pg} / \mathrm{mg}$ protein. Results are mean \pm SEM of 12 mice in each group. Comparison between APP and WT mice at each age by a Mann-Whitney test: ${ }^{* *} P<0.01,{ }^{* * *} P<0.001$; comparison of the 3 classes of age (Kruskall-Wallis test) followed by two-by-two comparisons (Dunn's multiple comparison test in APP mice): ${ }^{\#} P<0.05$ for 6 -month old versus 12 -month old APP mice, ${ }^{\# \# \# ~} P<0.001$ for 3 -month old versus 12-month old APP mice. 

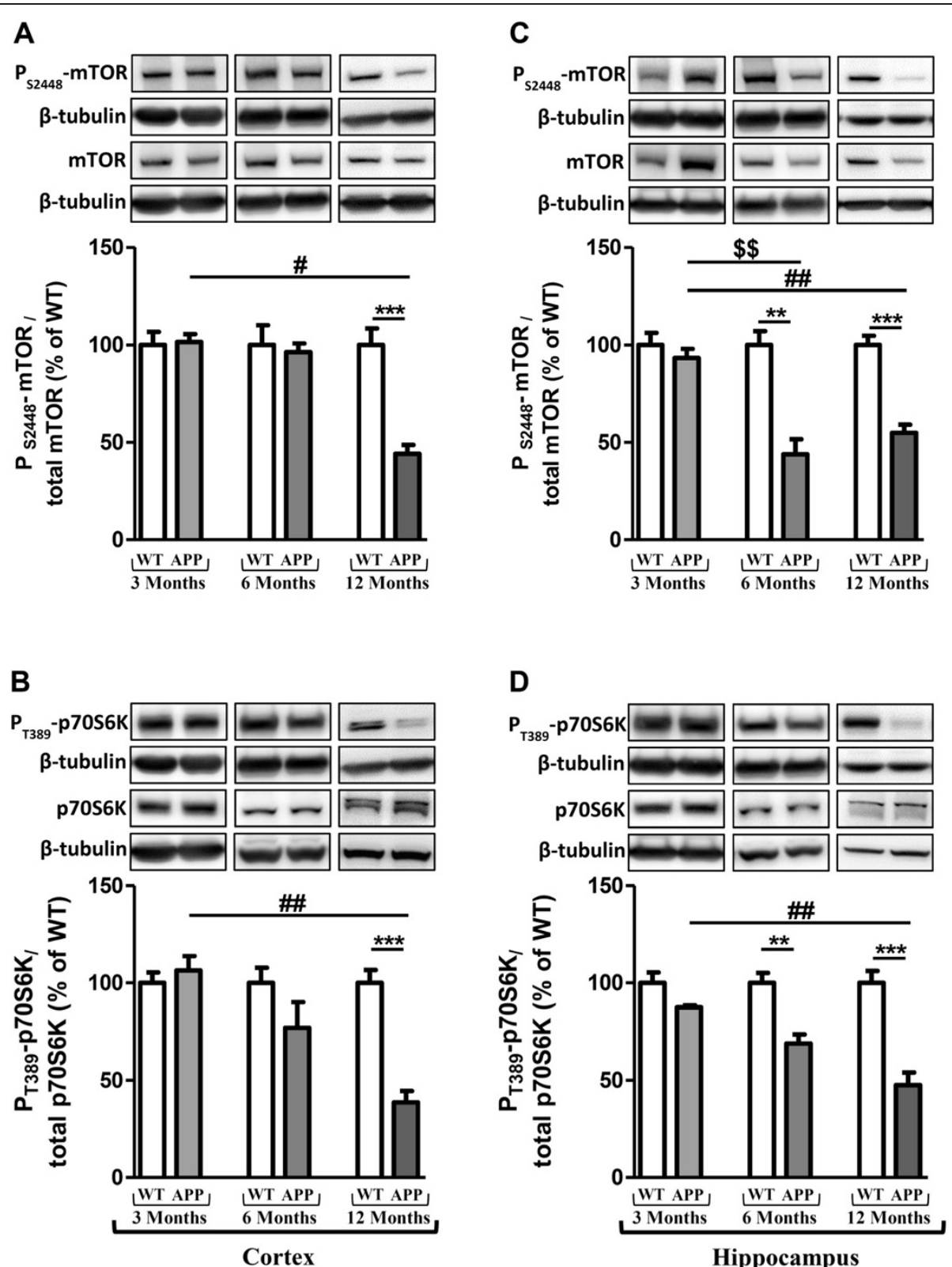

Hippocampus

Figure $\mathbf{2}$ Changes in activation of the mammalian Target of Rapamycin (mTOR) signaling pathway. Representative immunoblots of

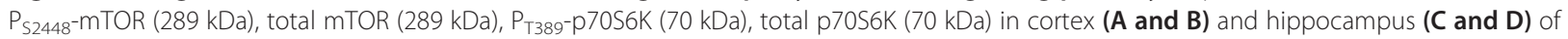
wild-type (WT) mice and APPswePS1dE9 (APP) at 3, 6 and 12 months of age. Semi-quantitative analysis of immunoblot was performed using Gene Tools software (Syngene, Ozyme, Saint-Quentin-en-Yvelines, France). The immunoreactivity of protein was normalized to $\beta$-tubulin ( $55 \mathrm{kDa}$ ) immunoreactivity. The results are expressed as arbitrary units (\% of WT). Results are mean \pm SEM of 12 mice. Comparison between APP and WT mice at each age by a Mann-Whitney test: ${ }^{* *} P<0.01,{ }^{* * *} P<0.001$; comparison of the 3 classes of age (Kruskall-Wallis test) followed by two-by-two comparisons (Dunn's multiple comparison test in APP mice): ${ }^{\$ \$} P<0.01$ for 3-month old versus 6-month old APP mice, ${ }^{\#} P<0.05$, ${ }^{\# \#} P<0.01$ for 6 -month old versus 12-month old APP mice.

variations during the life in APPswePS1dE9, the levels of Beclin-1 expression in twelve-month old APPswePS1dE9 mice were also significantly lower than those of six-month old APPswePS1dE9 mice in hippocampus and three-month old APPswePS1dE9 mice in both brain areas (Figure 3A and C). p62 is an autophagic receptor which recognizes ubiquitinylated proteins and interacts with LC3-II at the forming autophagosome [42]. LC3 is present in free cytoplasmic form as LC3-I which, when is associated to phosphatidylethanolamine (through an ubiquitin-like conjugation reaction) of the membrane of autophagosome, produces 

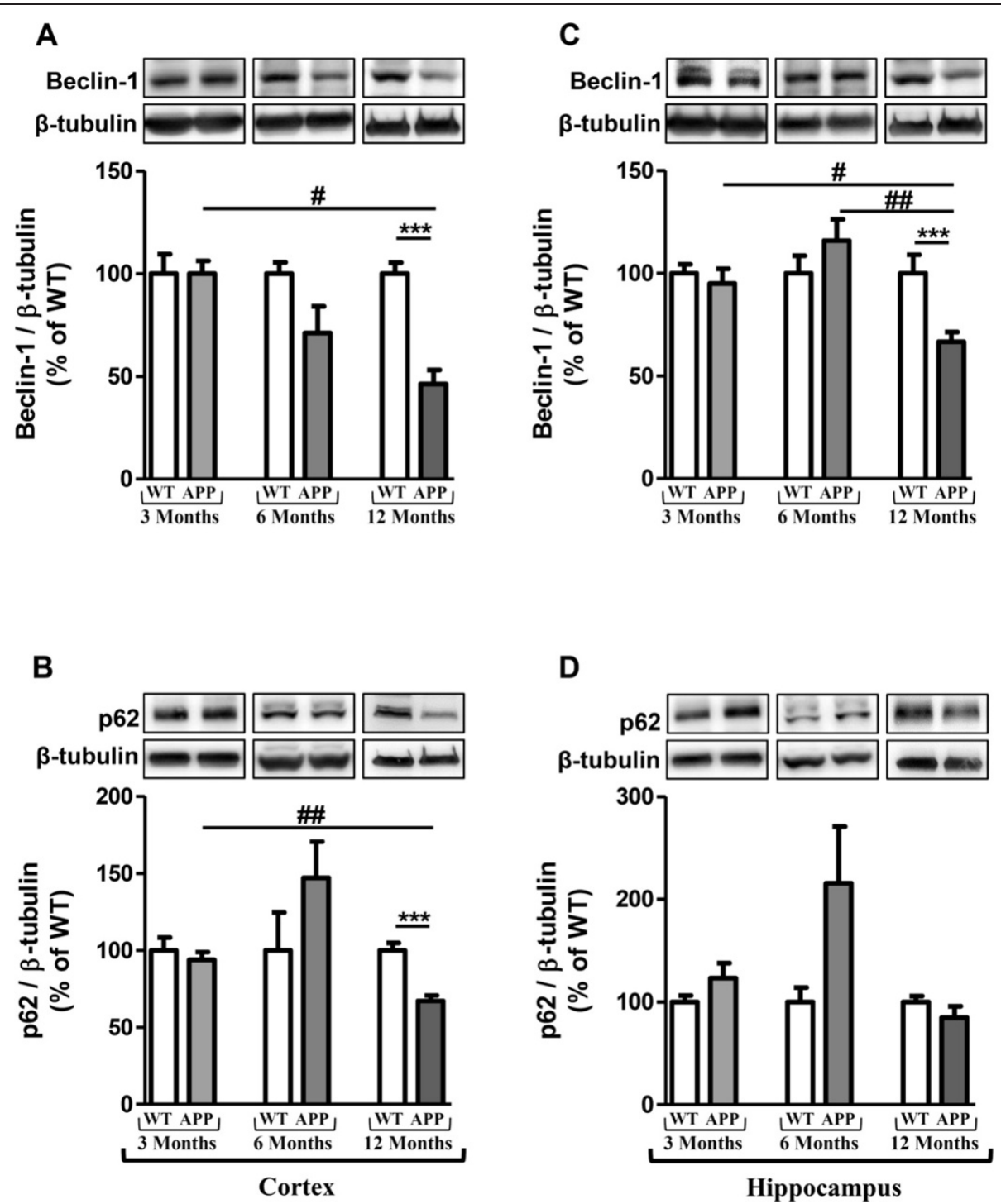

Figure 3 Longitudinal monitoring of Beclin-1 and p62 in the brain of APPswePS1dE9 mice. Representative immunoblots of Beclin-1 (60 kDa) and p62 (62 kDa) in cortex (A and B, respectively) and hippocampus ( $\mathbf{C}$ and $\mathbf{D}$, respectively) of wild-type (WT) and APPswePS1dE9 (APP) mice at 3,6 and 12 months of age. Semi-quantitative analysis of immunoblot was performed using Gene Tools software (Syngene, Ozyme, Saint-Quentin-enYvelines, France). The immunoreactivity of protein was normalized to $\beta$-tubulin ( $55 \mathrm{kDa}$ ) immunoreactivity. The results are expressed as arbitrary units (\% of WT). Results are mean \pm SEM of 12 mice. Comparison between APP and WT mice at each age by a Mann-Whitney test: ${ }^{* * *} P<0.001$; Comparison of the three classes of age (Kruskall-Wallis test) followed by two-by-two comparisons (Dunn's multiple comparison test in APP mice): ${ }^{\#} P<0.05$, ${ }^{\# \#} P<0.01$ compared to 12-month old APPswePS1dE9.

LC3-II form, a useful marker of autophagic membranes [42]. Results showed that the p62 expression decreased in cortex of APPswePS1dE9 mice at 12 months of age (30\% compared to WT mice) and was significantly different compared to 3-month old APPswePS1dE9 mice (Figure 3B and D). Contrary to Beclin-1 and p62, no change was observed in expressions of LC3-I and LC3-II (Figure 4).

As protein changes of autophagy were observed only at 12 months of age, a transcriptional analysis was performed to complete this monitoring and data showed no significant difference for all markers between APPswePS1dE9 and WT at 12 months of age (Table 1 ).

In addition, TEM revealed the presence of dystrophic neurites with a large accumulation of autophagic vesicles (AVs) with a dense compacted amorphous or multilamellar content both in cortex and hippocampus in APPswePS1dE9 mice at 12 months of age (Figure 5). No AVs and no dystrophic neurites were depicted at three and six months of age in these transgenic mice (data not shown). 

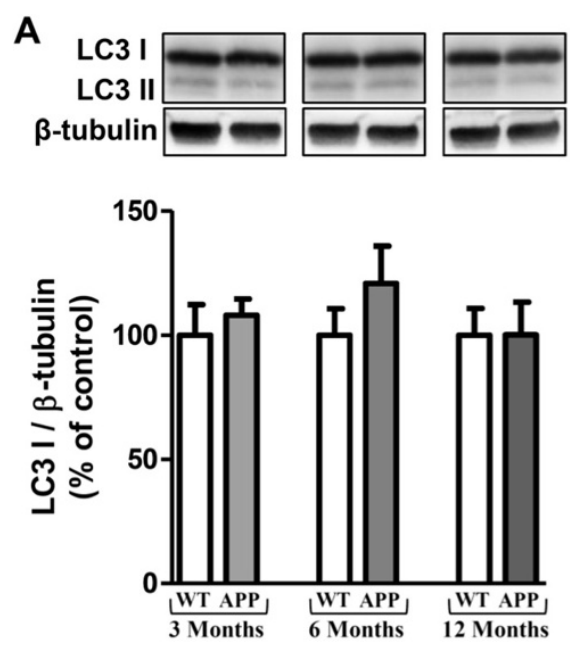

B

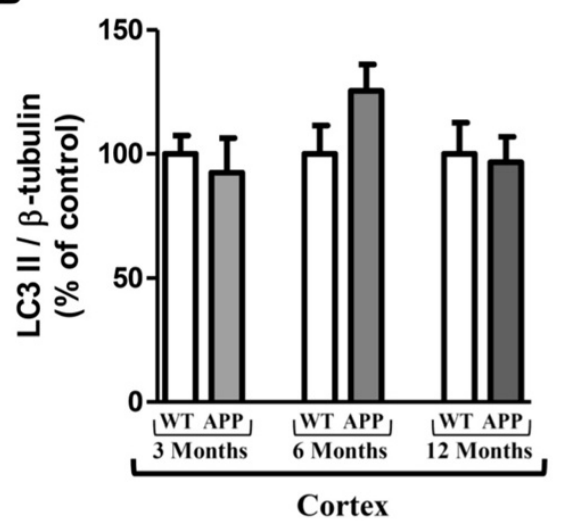

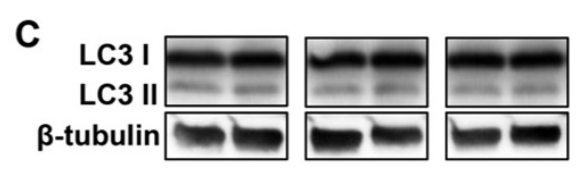

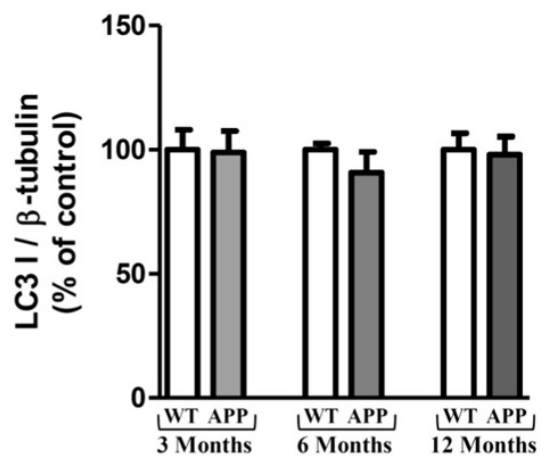

D

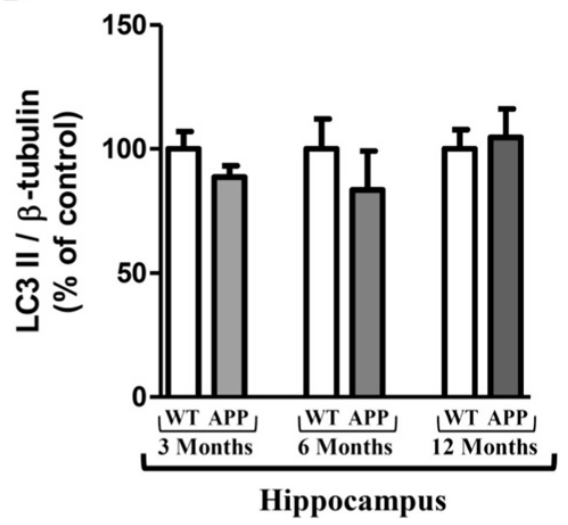

Figure 4 Longitudinal monitoring of LC3 in the brain of APPswePS1dE9 mice. Representative immunoblots of LC3-I (18 kDa), LC3-II (16 kDa) in cortex (A and $\mathbf{B}$, respectively) and hippocampus (C and D, respectively) of wild-type (WT) and APPswePS1dE9 (APP) mice at 3,6 and 12 months of age. Semi-quantitative analysis of immunoblot was performed using Gene Tools software (Syngene, Ozyme, Saint-Quentin-en-Yvelines, France). The immunoreactivity of protein was normalized to $\beta$-tubulin $(55 \mathrm{kDa})$ immunoreactivity. The results are expressed as arbitrary units (\% of WT). Results are mean \pm SEM for 12 mice.

Correlation between Beclin-1 and IL-1 $\beta$ levels in cortex and hippocampus of APPswePS1dE9 mice

In the 12-month old APPswePS1dE9 mouse group, inflammation and autophagy were significantly correlated. Indeed, Beclin- 1 and IL-1 $\beta$ levels in cortex and in hippocampus were positively correlated (Figure 6). In addition,

Table 1 Monitoring of the mRNA autophagy marker levels in APPswePS1dE9

\begin{tabular}{lllll}
\hline & Wild-type & & \multicolumn{2}{l}{ APPswePS1dE9 } \\
\hline & Cortex & Hippocampus & Cortex & Hippocampus \\
Beclin-1 & $1.00 \pm 0.26$ & $1.00 \pm 0.18$ & $1.22 \pm 0.21$ & $0.91 \pm 0.05$ \\
p62 & $1.00 \pm 0.12$ & $1.00 \pm 0.08$ & $0.93 \pm 0.12$ & $1.10 \pm 0.06$ \\
LC3 & $1.00 \pm 0.07$ & $1.00 \pm 0.08$ & $0.79 \pm 0.05$ & $0.82 \pm 0.09$ \\
\hline
\end{tabular}

Total RNA was isolated from cortex and hippocampus of 12-month old APPswePS1dE9 and WT mice and TaqMan real-time PCR was performed in an ABI 7500 real-time PCR system as described in Materials and methods. Results were normalized relatively to mean of WT mice $(n=12)$.
Beclin-1 levels were positively correlated with those of TNF- $\alpha$ in cortex (rho $=0.60 ; P=0.007$ ). These correlations mean that in the APPswePS1dE9 group, the higher the IL-1 $\beta$ and TNF- $\alpha$ levels, the higher the Beclin-1 expression.

Relationships between mTOR signaling pathway and cytokine production were observed in 12-month old APPswePS1dE9 mice. In hippocampus, TNF- $\alpha$ levels were inversely correlated with the mTOR activation (rho $=-0.46 ; P=0.04$ ). In cortex, IL-1 $\beta$ and TNF- $\alpha$ levels were inversely correlated with the p70S6K activation (rho $=-0.48 ; P=0.04$ and rho $=-0.49 ; P=0.03$, respectively). These correlations indicate that the higher the IL-1 $\beta$ and TNF- $\alpha$ levels, the lower the mTOR signaling pathway activation. Another interesting result is that cortical levels of Beclin-1 expression were positively correlated with those of p62 (rho $=0.75, P=0.0002)$. This last correlation would strengthen the results demonstrating a 

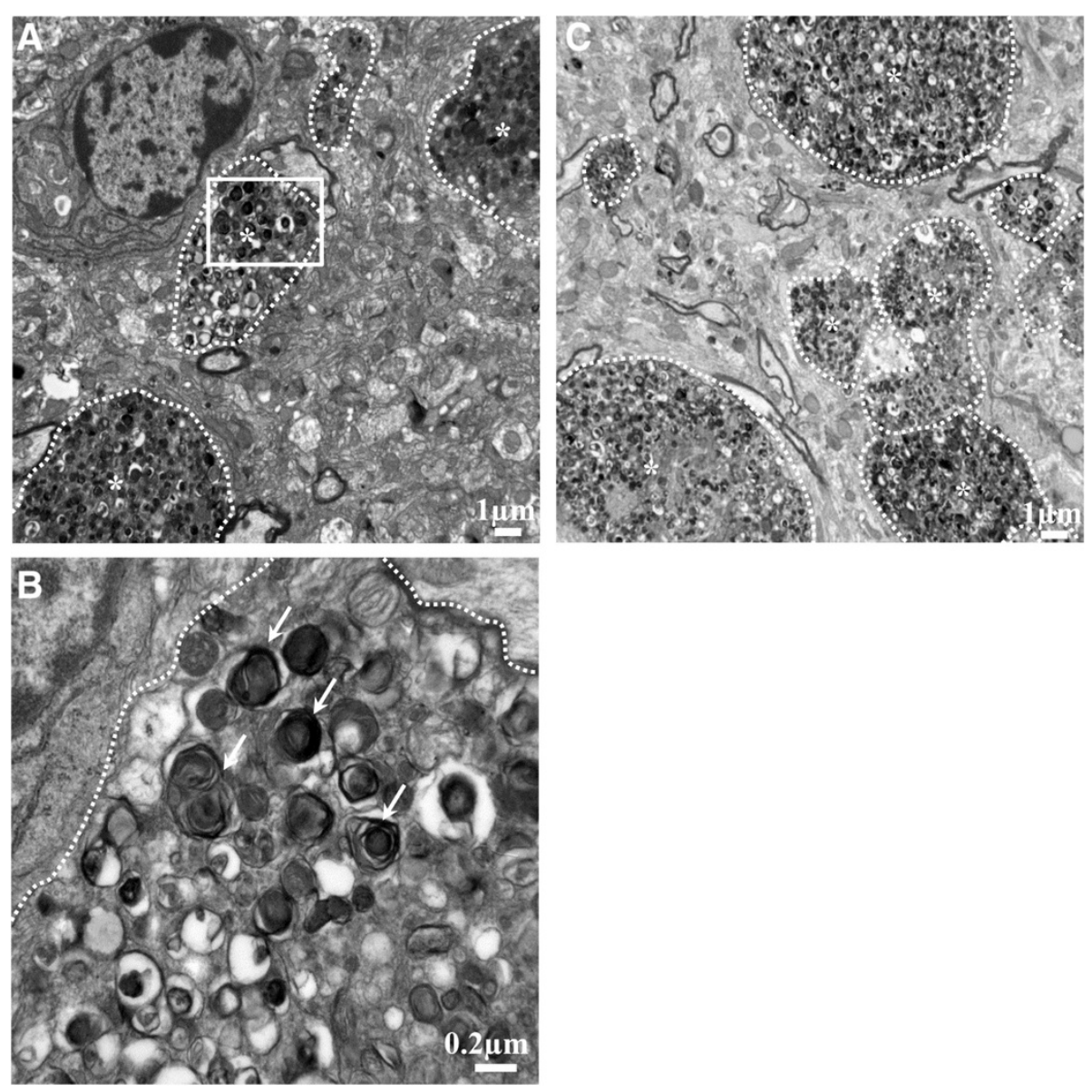

Figure 5 Ultrastructure of cortex and hippocampus in 12-month old APPswePS1dE9 mice. Transmission electron microscopy (TEM) cortical (A) and hippocampal (C) representative images ( $n=3$ mice) showed dystrophic neurites (marked by *) with a large accumulation of autophagic vesicles (AVs). (B) represents a magnified region of interest (defined by a white square in image (a)) within many AVs with a dense compacted amorphous or multilamellar content as indicated by white arrows.
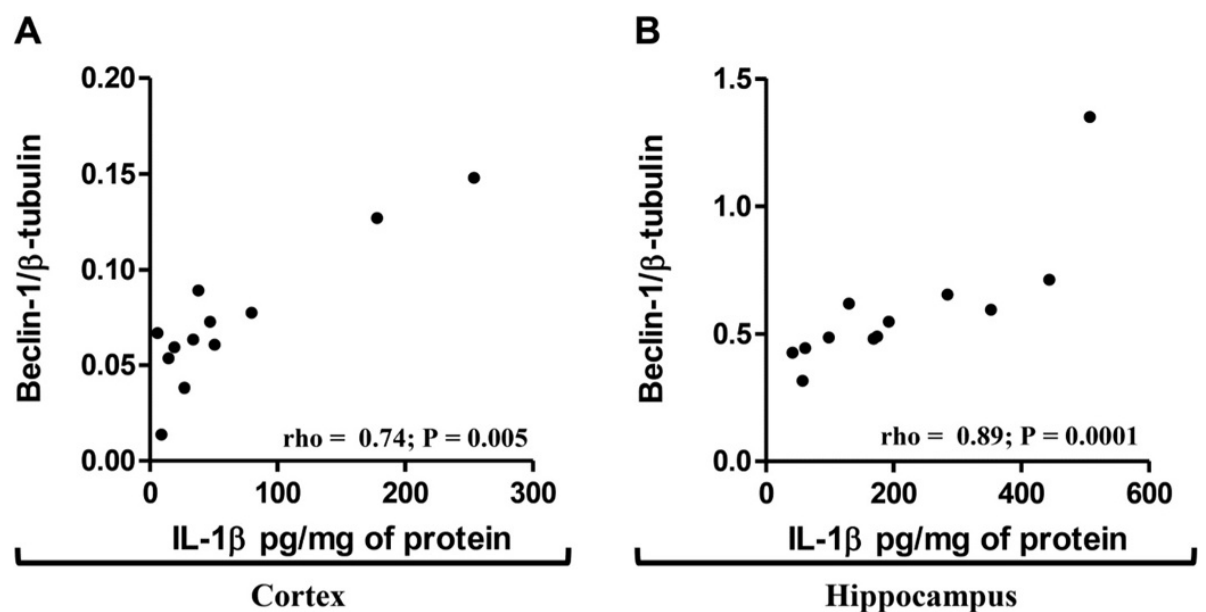

Figure 6 Correlation between Beclin-1 and IL-1 $\beta$ levels in cortex and hippocampus of 12-month old APPswePS1dE9 mice. Spearman correlations were performed between levels of $\mathrm{IL}-1 \beta$ and Beclin-1 in the cortex (A) and hippocampus (B) of 12-month old APPswePS1dE9 mice $(\mathrm{n}=12)$. rho and $P$-values were indicated on graphs. The level of significance was $P<0.05$. 
blocking of autophagic flux in 12- month old APPswePS1dE9 mice.

\section{Discussion}

There is mounting evidence that the control of autophagy is impaired in $\mathrm{AD}$ as well as in many other neurodegenerative diseases with protein aggregation [43,44]. Furthermore, many studies have revealed that the stimulation of autophagy can reduce $A \beta$ accumulation and alleviate memory deficits in transgenic AD mice [45-48]. As with many other neurodegenerative diseases, $\mathrm{AD}$ is also marked by a large inflammatory response and recent data are consistent with the hypothesis that $\mathrm{A} \beta$-induced activation of the NLRP3 inflammasome enhances AD progression by mediating a harmful chronic inflammatory tissue response [11-13].

The crosstalk between autophagy and inflammation is mainly described at peripheral level in particular in inflammatory bowel diseases [49], type 2 diabetes [50], cardiac disorders [51] and cystic fibrosis [52]. Recently, we showed, in primary cultures of neurons, astrocytes and microglia, that IL-1 $\beta$ induced autophagy with accumulation of many acidic vesicles loaded with autophagic markers (p62 and LC3) in microglia, whereas A 342 prevented the effects of exogenous IL-1 $\beta$ in the production of inflammatory factors and in autophagy impairment [53]. In this present study, we wanted to explore correlations between autophagy and inflammation in vivo by using APPswePS1dE9 mice which displayed amyloid plaques and an inflammatory response at an early stage of the life and progressively increase with age $[37,38]$. However, their longitudinal status of autophagy has never been studied.

In three, six- and twelve-month old mice, results showed that mice displayed a large increase in IL-1 $\beta$ and TNF- $\alpha$, a significant decrease in mTOR (a negative regulator of autophagy) and Beclin-1 associated with an accumulation of autophagic vacuoles (AVs) with a dense compacted amorphous or multilamellar content at twelve months of age in hippocampus and cortex. Interestingly, correlation analyses showed that Beclin-1 was positively correlated with IL- $1 \beta$ and TNF- $\alpha$ and these cytokine levels were inversely correlated with the levels of mTOR activation at 12 months of age.

The monitoring of inflammation in APPswePS1dE9 versus WT mice at 3, 6 and 12 months of age showed that APPswePS1dE9 mice displayed cytokine production, in particular IL-1 $\beta$ in cortex at 12 months of age and hippocampus from 6 months, but TNF- $\alpha$ levels increased only in hippocampus at 12 months and were less than $10 \mathrm{pg} / \mathrm{mg}$ protein as previously described [37,38]. In line with our work, Jin et al. did not find any modification of the levels of IL-6. Similar changes in cytokine expression have been shown in other transgenic mice and reflected those observed in AD patients [54].
Concerning autophagy, it is well-known that the mTOR activation is a primordial inhibitory signal [55-59]. In these APPswePS1dE9 mice, a large decrease of the activation of mTOR and its downstream substrate p70S6K was observed according to previous findings in other transgenic mouse AD models [60-63]. However, in some transgenic mouse models of $\mathrm{AD}$, the mTOR activation was not modified while the p70S6K activation decreased [64]. In two independent mouse models of $\mathrm{AD}$, rapamycin, through inhibition of mTOR signaling, rescued cognitive deficits by suppressing extracellular $A \beta$ deposition and intracellular tau accumulation [45,63]. Interestingly, this treatment induced autophagy marked by increased expression of Atg 7, Atg5-Atg12, decrease in p62, no modification of LC3 expression and controversial results surrounding LC3-II expression in PDAPP and 3xTg-AD mice $[45,46]$. In our experimental conditions, APPswePS1dE9 mice not treated with rapamycin displayed a large inactivation of mTOR signaling pathway from 6 months of age in hippocampus, a significant decrease of Beclin-1 both in cortex and hippocampus and p62 in cortex at 12 months of age, but no modification of LC3-I and LC3-II expression. These decreases of autophagic markers were significantly different from mice at three and six months of age and were associated with extensive accumulation of autophagic vesicles either with a dense compacted amorphous or multilamellar content within dystrophic neurites as previously described in other AD transgenic mice $[35,46,65,66]$ and in brains of $\mathrm{AD}$ patients [29].

Recent studies have demonstrated that the $p 62$ gene expression and cytoplasmic p62 protein levels are significantly reduced in the frontal cortex of $A D$ patients compared to that of control subjects $[32,67]$. Here, no modification of transcriptional expression was observed while a large decrease of its protein expression was quantified only in cortex of APPswePS1dE9 mice as in cortex of $\mathrm{AD}$ patients. This decrease could be explained by its sequestration into amyloid aggregates reducing the accessibility of p62 protein for the regulation of signaling, trafficking and autophagic clearance of ubiquitinated proteins [68]. Moreover, studies in p62 knockout mice have clearly demonstrated that the lack of p62 protein leads to the neuropathological lesions including the accumulation of hyperphosphorylated tau and neurofibrillary tangles, synaptic deficiencies with loss of working memory and neuronal apoptosis [69].

In addition, it was shown that an inhibition of p62 resulted in the formation of mis-regulated autophagosomes with multilayer membranes and an autophagic cell death in carcinoma cells [27]. The expression of p62 is also determined by availability of lysosomalderived amino acids used for de novo synthesis of $\mathrm{p} 62$ [70]. However in $\mathrm{AD}$, it is well-known that lysosomal acidification is disrupted [71,72]. 
The reduced Beclin-1 protein levels may be related to caspase-cleavage as shown in frontal cortex tissue from moderate to severe AD cases [66,73-75]. Some miRNA, miR-30a and miR-376b target Beclin mRNA [76,77] and miR-30a levels have been shown to increase in cerebrospinal fluid of $A D$ patients [70]. Another explanation for the reduced expression of Beclin-1 could be a nonfunctional sequestration of Beclin-1 as it is a molecular platform assembling an interactome, with stimulating and suppressive components, which regulate the initiation of the autophagosome formation [75]. In AD transgenic mice, Beclin-1 reduced neuronal autophagy, disrupted lysosomes, promoted intracellular and extracellular $A \beta$ accumulation, and resulted in neurodegeneration [35]. On the contrary, increased expression of it reversed these impairments in mice [78,79]. Recent studies position Beclin-1 as a link between autophagy, retromer trafficking, and receptor-mediated phagocytosis [80]. Indeed, Beclin-1, together with its phosphatidylinositol 3-kinase (PI3K) binding partner, Vps34, played a role in receptor-mediated phagocytosis by regulating the retromer complex in microglia [80].

Interestingly, results showed positive correlation between Beclin-1 and IL-1 $\beta$ in cortex and hippocampus and with TNF- $\alpha$ in cortex, suggesting relationships between inflammatory response and autophagy impairment in 12-month old APPswePS1dE9 mice. It is known that many inflammasomal receptors, in particular NLRP4, could interact with Beclin-1 and inhibit autophagocytosis [81]. Furthermore, the levels of these cytokines were inversely correlated with the activation of mTOR signaling pathway. It is known that the mTOR signaling pathway can inhibit the inflammatory response in microglia and monocytes by reducing NF- $\mathrm{kB}$ activation and enhancing STAT3 activity and anti-inflammatory IL-10 production $[82,83]$, whereas inhibition of mTOR with or without rapamycin has reciprocal effects [84-86]. Therefore, in the APPswePS1dE9 mouse model, the inhibition of the mTOR signaling pathway could participate in the inflammatory response which could impair autophagy. However, mTORC1 colocalizes with the Transcription Factor EB (TFEB), a master regulator of lysosomal biogenesis on the lysosomal membrane, leading to inhibition of TFEB activity by mTORC1-induced phosphorylation. Conversely, pharmacological inhibition of mTORC1, as well as starvation and lysosomal disruption, activates TFEB by promoting its nuclear translocation for lysosomal biogenesis and autophagy [87-90]. However, in the APPswePS1dE9 mouse model there was an accumulation of AVs that may have been due to a dysfunction of lysosomal activity. It is known that mutation of PS1 leads to the accumulation of immature unglycosylated $\mathrm{v}$-ATPase which is needed in the acidification of autolysosomes and/or lysosomes with abnormal accumulation of late-stage autophagosomes with undigested contents just like the ultrastructures present in $\mathrm{AD}$ neurons $[71,72,91]$. Recently, inhibition of GSK-3 $\beta$ or cystatin B, an endogenous cathepsin inhibitor, could restore lysosomal acidification that in turn enables clearance of $A \beta$ burdens and reactivation of mTOR. These changes facilitate amelioration in cognitive function in $5 \times \mathrm{FAD}$ and TgCRND8 mice $[48,60]$.

For LC3, no variation is observed in APPswePS1dE9 mice regardless of age compared to WT mice. Other authors show no modification of LC3-I $[45,46]$. For LC3-II isoform, the results in the literature are contradictory despite the absence of variation of LC3-I. Indeed, some have observed an increase in the expression of LC3-II at a very late age of 18 months in $3 \times \mathrm{Tg}-\mathrm{AD}$ treated with rapamycin, which is known to inhibit mTOR and thus induce autophagy [46]. Other APP/PS1 mice (PS1M146L/APP751SL) aged 18 months also showed an accumulation of LC3-II in microsomal fractions and very little in the synaptosomes [92]. Other authors showed a decrease of LC3-II in PDAPP mice at the age of eight to nine months although treated for thirteen weeks with rapamycin since the age of four months [45].

Therefore, the expression rate of LC3-II varies depending on the age of the mice and its subcellular localization. Furthermore, we cannot exclude a variation depending on the transgenic AD model.

\section{Conclusion}

Taken together, these results highlighted the negative impact of IL- $1 \beta$ and TNF- $\alpha$ in the activation of the mTOR signaling pathway (negative correlation) and in the induction of autophagy (positive correlation with Beclin-1) which remained locked and led to the accumulation of AVs in APPswePS1dE9 at 12 months of age. This first demonstration of the relationships between inflammation and autophagy in vivo should into account in new therapeutic strategies to prevent inflammation and/or stimulate autophagy in advanced neurodegenerative process such as AD. Furthermore, development of similar but inactive molecules to Beclin-1 could limit its non-functional sequestration and allow the maintenance of a sufficient level of free active Beclin-1 to initiate autophagic flux.

\section{Abbreviations}

AD: Alzheimer's disease; A $\beta$ : $\beta$-amyloid peptide; APP: amyloid precursor protein; AVs: autophagic vesicles; bp: base pair; BSA: bovine serum albumin; CNS: central nervous system; DTT: dithiothreitol; ELISA: enzyme-linked immunosorbent assay; FAD: familial Alzheimer's disease; FAM: 6-carboxy-fluorescein; HRP: horseradish peroxidase; Ig: immunoglobulin; IL: interleukin; ip: intraperitoneally;

LC3: microtubule-associated protein 1/light chain 3; LDS: lithium dodecylsulfate; LPS: lipopolysaccharide; mTOR: mammalian Target of Rapamycin: NaF: sodium fluoride; NF-kB: nuclear factor-kappa B; NLR: nucleotide oligomerization domain receptors; OD: optical density; PCR: polymerase chain reaction; PBS: phosphate- buffered saline; PFA: paraformaldehyde; PI3K: phosphatidylinositol 3-kinase; p62/SQMT1: sequestosome 1; PMSF: phenylmethylsulfonyl fluoride; PrP: prion protein; PSEN1 or 
PS1: presenilin 1; RT: room temperature; SDS: sodium dodecyl-sulfate; TAMRA: 6-carboxytetramethylrhodamine; TBST: Tris-buffered saline/ Tween; TEM: transmission electron microscopy; TFEB: Transcription Factor EB; TMB: tetramethylbenzidine; TNF: tumor necrosis factor; WT: wild-type.

\section{Competing interests}

The authors declare that they have no competing interests.

\section{Authors' contributions}

AF performed the research, analyzed the data, their statistical significance and wrote the paper; ARB carried out TaqMan real-time PCR and analyzed the data; NQ and BF carried out TEM; TJ participated in design and coordination of this work; DC genotyped all mice and participated in brain tissue preparation for biochemical analysis; MP followed the research and provided relevant remarks throughout the work; FT participated in the design of the study and followed the work, GP conceived of the study, and organized its design and coordination and helped to draft the manuscript. All authors read and approved the final manuscript.

\section{Acknowledgements}

This work was supported by a grant from 'Ligue Européenne Contre la Maladie d'Alzheimer' (LECMA), by Poitiers University and Poitiers University Hospital. The authors thanked Dr Stéphanie Ragot for her help in the statistical analysis.

\section{Author details}

${ }^{1}$ EA3808 molecular Targets and Therapeutic of Alzheimer's disease, University of Poitiers, 1 Rue Georges Bonnet, TSA 5110686073 Poitiers, Cedex 9, France. ${ }^{2}$ Pathology Department, Poitiers University Hospital, Poitiers F-86021, France. ${ }^{3}$ Geriatrics Department, Poitiers University Hospital, Poitiers F-86021, France. ${ }^{4}$ CMRR, Poitiers University Hospital, Poitiers F-86021, France. ${ }^{5} \mathrm{CIC}-\mathrm{P} 1402$ Poitiers University Hospital, Poitiers F-86021, France. ' 'Laboratory of Histology and Biology, Faculty of Medicine, University of Limoges, Limoges F-87025, France. ${ }^{7}$ Service d'histologie et de cytogénétique, Hôpital de la Mère et de l'Enfant, Limoges F-87025, France.

\section{Received: 20 April 2014 Accepted: 28 July 2014}

Published: 27 August 2014

\section{References}

1. Abraham CR, Selkoe DJ, Potter H: Immunochemical identification of the serine protease inhibitor alpha 1-antichymotrypsin in the brain amyloid deposits of Alzheimer's disease. Cell 1988, 52:487-501

2. Luber-Narod J, Rogers J: Immune system associated antigens expressed by cells of the human central nervous system. Neurosci Lett 1988, 94:17-22.

3. McGeer PL, Itagaki S, McGeer EG: Expression of the histocompatibility glycoprotein HLA-DR in neurological disease. Acta Neuropathol 1988, 76:550-557.

4. Rogers J, Luber-Narod J, Styren SD, Civin WH: Expression of immune system-associated antigens by cells of the human central nervous system: relationship to the pathology of Alzheimer's disease. Neurobio/ Aging 1988, 9:339-349.

5. Rodriguez JJ, Olabarria M, Chvatal A, Verkhratsky A: Astroglia in dementia and Alzheimer's disease. Cell Death Differ 2009, 16:378-385.

6. Fuller S, Steele M, Munch G: Activated astroglia during chronic inflammation in Alzheimer's disease - do they neglect their neurosupportive roles? Mutat Res 2010, 690:40-49.

7. Wyss-Coray T, Loike JD, Brionne TC, Lu E, Anankov R, Yan F, Silverstein SC, Husemann J: Adult mouse astrocytes degrade amyloid-beta in vitro and in situ. Nat Med 2003, 9:453-457.

8. Wyss-Coray T, Rogers J: Inflammation in Alzheimer disease - a brief review of the basic science and clinical literature. Cold Spring Harb Perspect Med 2012, 2:a006346.

9. Salminen A, Kauppinen A, Suuronen T, Kaarniranta K, Ojala J: ER stress in Alzheimer's disease: a novel neuronal trigger for inflammation and Alzheimer's pathology. J Neuroinflammation 2009, 6:41.

10. Heneka MT, O'Banion MK, Terwel D, Kummer MP: Neuroinflammatory processes in Alzheimer's disease. J Neural Transm 2010, 117:919-947.
11. Akiyama H, Barger S, Barnum S, Bradt B, Bauer J, Cole GM, Cooper NR, Eikelenboom P, Emmerling M, Fiebich BL, Finch CE, Frautschy S, Griffin WS, Hampel H, Hull M, Landreth G, Lue L, Mrak R, Mackenzie IR, McGeer PL, O'Banion MK, Pachter J, Pasinetti G, Plata-Salaman C, Rogers J, Rydel R, Shen Y, Streit W, Strohmeyer R, Tooyoma I, et al: Inflammation and Alzheimer's disease. Neurobiol Aging 2000, 21:383-421.

12. Heneka MT, Kummer MP, Stutz A, Delekate A, Schwartz S, Vieira-Saecker A, Griep A, Axt D, Remus A, Tzeng TC, Gelpi E, Halle A, Korte M, Latz E, Golenbock DT: NLRP3 is activated in Alzheimer's disease and contributes to pathology in APP/PS1 mice. Nature 2013, 493:674-678.

13. Shi S, Wang Z, Qiao Z: The multifunctional anti-inflammatory drugs used in the therapy of Alzheimer's disease. Curr Med Chem 2013, 20:2583-2588.

14. Sardi F, Fassina L, Venturini L, Inguscio M, Guerriero F, Rolfo E, Ricevuti G: Alzheimer's disease, autoimmunity and inflammation. The good, the bad and the ugly. Autoimmun Rev 2011, 11:149-153.

15. Imbimbo BP: An update on the efficacy of non-steroidal anti-inflammatory drugs in Alzheimer's disease. Expert Opin Investig Drugs 2009, 18:1147-1168.

16. Nguyen HT, Lapaquette P, Bringer MA, Darfeuille-Michaud A: Autophagy and Crohn's disease. J Innate Immun 2013, 5:434-443.

17. Ramos PS, Criswell LA, Moser KL, Comeau ME, Williams AH, Pajewski NM, Chung SA, Graham RR, Zidovetzki R, Kelly JA, Kaufman KM, Jacob CO, Vyse TJ, Tsao BP, Kimberly RP, Gaffney PM, Alarcon-Riquelme ME, Harley JB, Langefeld CD: A comprehensive analysis of shared loci between systemic lupus erythematosus (SLE) and sixteen autoimmune diseases reveals limited genetic overlap. PLoS Genet 2011, 7:e1002406.

18. Martin $\sqcup$, Gupta J, Jyothula SS, Butsch Kovacic M, Biagini Myers JM, Patterson TL, Ericksen MB, He H, Gibson AM, Baye TM, Amirisetty S, Tsoras AM, Sha Y, Eissa NT, Hershey GK: Functional variant in the autophagy-related 5 gene promotor is associated with childhood asthma. PLoS One 2012, 7:e33454

19. Raychaudhuri S, Thomson BP, Remmers EF, Eyre S, Hinks A, Guiducci C, Catanese JJ, Xie G, Stahl EA, Chen R, Alfredsson L, Amos Cl, Ardlie KG, Barton A, Bowes J, Burtt NP, Chang M, Coblyn J, Costenbader KH, Criswell LA, Crusius JB, Cui J, De Jager PL, Ding B, Emery P, Flynn E, Harrison P, Hocking L, Huizinga TW, Kastner DL, et al: Genetic variants at CD28, PRDM1 and CD2/CD58 are associated with rheumatoid arthritis risk. Nat Genet 2009, 41:1313-1318.

20. Zeng M, Wei X, Wu Z, Li W, Li B, Zhen Y, Chen J, Wang P, Fei Y: NF-kappaB-mediated induction of autophagy in cardiac ischemia/ reperfusion injury. Biochem Biophys Res Commun 2013, 436:180-185.

21. Harris J, De Haro SA, Master SS, Keane J, Roberts EA, Delgado M, Deretic V: T helper 2 cytokines inhibit autophagic control of intracellular Mycobacterium tuberculosis. Immunity 2007, 27:505-517.

22. Saitoh T, Fujita N, Jang MH, Uematsu S, Yang BG, Satoh T, Omori H, Noda T, Yamamoto N, Komatsu M, Tanaka K, Kawai T, Tsujimura T, Takeuchi O, Yoshimori T, Akira S: Loss of the autophagy protein Atg16L1 enhances endotoxin-induced IL-1 beta production. Nature 2008, 456:264-268.

23. Harris J, Hartman M, Roche C, Zeng SG, O'Shea A, Sharp FA, Lambe EM, Creagh EM, Golenbock DT, Tschopp J, Kornfeld H, Fitzgerald KA, Lavelle EC: Autophagy controls IL-1 beta secretion by targeting pro-IL-1 beta for degradation. J Biol Chem 2011, 286:9587-9597.

24. Shi CS, Shenderov K, Huang NN, Kabat J, Abu-Asab M, Fitzgerald KA, Sher A, Kehrl JH: Activation of autophagy by inflammatory signals limits IL-1beta production by targeting ubiquitinated inflammasomes for destruction. Nat Immunol 2012, 13:255-263.

25. Chen S, Sun B: Negative regulation of NLRP3 inflammasome signaling. Protein Cell 2013, 4:251-258.

26. Yuk JM, Jo EK: Crosstalk between autophagy and inflammasomes. Mol Cells 2013, 36:393-399.

27. Hara T, Nakamura K, Matsui M, Yamamoto A, Nakahara Y, Suzuki-Migishima R, Yokoyama M, Mishima K, Saito I, Okano H, Mizushima N: Suppression of basal autophagy in neural cells causes neurodegenerative disease in mice. Nature 2006, 441:885-889.

28. Komatsu M, Kominami E, Tanaka K: Autophagy and neurodegeneration. Autophagy 2006, 2:315-317.

29. Nixon RA, Wegiel J, Kumar A, Yu WH, Peterhoff C, Cataldo A, Cuervo AM: Extensive involvement of autophagy in Alzheimer disease: an immunoelectron microscopy study. J Neuropathol Exp Neurol 2005, 64:113-122.

30. Yu WH, Cuervo AM, Kumar A, Peterhoff CM, Schmidt SD, Lee JH, Mohan PS, Mercken M, Farmery MR, Tjernberg LO, Jiang Y, Duff K, Uchiyama Y, Naslund J, Mathews PM, Cataldo AM, Nixon RA: Macroautophagy - a novel beta-amyloid peptide-generating pathway activated in Alzheimer's disease. J Cell Biol 2005, 171:87-98. 
31. Cataldo AM, Peterhoff CM, Troncoso JC, Gomez-Isla T, Hyman BT, Nixon RA Endocytic pathway abnormalities precede amyloid beta deposition in sporadic Alzheimer's disease and Down syndrome: differential effects of APOE genotype and presenilin mutations. Am J Pathol 2000, 157:277-286.

32. Cataldo AM, Peterhoff CM, Schmidt SD, Terio NB, Duff K, Beard M, Mathews PM, Nixon RA: Presenilin mutations in familial Alzheimer disease and transgenic mouse models accelerate neuronal lysosomal pathology. J Neuropathol Exp Neurol 2004, 63:821-830.

33. Nixon RA: Autophagy, amyloidogenesis and Alzheimer disease. J Cell Sci 2007, 120:4081-4091.

34. Boland B, Kumar A, Lee S, Platt FM, Wegiel J, Yu WH, Nixon RA: Autophagy induction and autophagosome clearance in neurons: relationship to autophagic pathology in Alzheimer's disease. J Neurosci 2008, 28:6926-6937.

35. Pickford F, Masliah E, Britschgi M, Lucin K, Narasimhan R, Jaeger PA, Small S, Spencer B, Rockenstein E, Levine B, Wyss-Coray T: The autophagy-related protein beclin 1 shows reduced expression in early Alzheimer disease and regulates amyloid beta accumulation in mice. J Clin Invest 2008, 118:2190-2199.

36. Spencer B, Potkar R, Trejo M, Rockenstein E, Patrick C, Gindi R, Adame A, Wyss-Coray T, Masliah E: Beclin 1 gene transfer activates autophagy and ameliorates the neurodegenerative pathology in alpha-synuclein models of Parkinson's and Lewy body diseases. J Neurosci 2009, 29:13578-13588.

37. Ruan L, Kang Z, Pei G, Le Y: Amyloid deposition and inflammation in APPswe/PS1dE9 mouse model of Alzheimer's disease. Curr Alzheimer Res 2009, 6:531-540

38. Couturier J, Paccalin M, Lafay-Chebassier C, Chalon S, Ingrand I, Pinguet J, Pontcharraud R, Guillard O, Fauconneau B, Page G: Pharmacological inhibition of PKR in APPswePS1dE9 mice transiently prevents inflammation at 12 months of age but increases Abeta42 levels in the late stages of the Alzheimer's disease. Curr Alzheimer Res 2012, 9:344-360.

39. Fenton TR, Gout IT: Functions and regulation of the $70 \mathrm{kDa}$ ribosomal S6 kinases. Int J Biochem Cell Biol 2011, 43:47-59.

40. Chong ZZ, Shang YC, Zhang L, Wang S, Maiese K: Mammalian target of rapamycin: hitting the bull's-eye for neurological disorders. Oxid Med Cell Longev 2010, 3:374-391.

41. Kang R, Zeh HJ, Lotze MT, Tang D: The Beclin 1 network regulates autophagy and apoptosis. Cell Death Differ 2011, 18:571-580.

42. Klionsky DJ, Abdalla FC, Abeliovich $\mathrm{H}$, Abraham RT, Acevedo-Arozena A, Adeli K, Agholme L, Agnello M, Agostinis P, Aguirre-Ghiso JA, Ahn HJ, Ait-Mohamed O, Ait-Si-Ali S, Akematsu T, Akira S, Al-Younes HM, Al-Zeer MA, Albert ML, Albin RL, Alegre-Abarrategui J, Aleo MF, Alirezaei M, Almasan A, Almonte-Becerril M, Amano A, Amaravadi R, Amarnath S, Amer AO, Andrieu-Abadie N, Anantharam $V$, et al: Guidelines for the use and interpretation of assays for monitoring autophagy. Autophagy 2012, 8:445-544.

43. Nixon RA: The role of autophagy in neurodegenerative disease. Nat Med 2013, 19:983-997.

44. Garcia-Arencibia M, Hochfeld WE, Toh PP, Rubinsztein DC: Autophagy, a guardian against neurodegeneration. Semin Cell Dev Biol 2010, 21:691-698.

45. Spilman P, Podlutskaya N, Hart MJ, Debnath J, Gorostiza O, Bredesen D, Richardson A, Strong R, Galvan V: Inhibition of mTOR by rapamycin abolishes cognitive deficits and reduces amyloid-beta levels in a mouse model of Alzheimer's disease. PLoS One 2010, 5:e9979.

46. Majumder S, Richardson A, Strong R, Oddo S: Inducing autophagy by rapamycin before, but not after, the formation of plaques and tangles ameliorates cognitive deficits. PLoS One 2011, 6:e25416.

47. Tian Y, Bustos V, Flajolet M, Greengard P: A small-molecule enhancer of autophagy decreases levels of Abeta and APP-CTF via Atg5-dependent autophagy pathway. FASEB J 2011, 25:1934-1942.

48. Yang DS, Stavrides P, Mohan PS, Kaushik S, Kumar A, Ohno M, Schmidt SD, Wesson DW, Bandyopadhyay U, Jiang Y, Pawlik M, Peterhoff CM, Yang AJ, Wilson DA, St George-Hyslop P, Westaway D, Mathews PM, Levy E, Cuervo AM, Nixon RA: Therapeutic effects of remediating autophagy failure in a mouse model of Alzheimer disease by enhancing lysosomal proteolysis. Autophagy 2011, 7:788-789.

49. Randall-Demllo S, Chieppa M, Eri R: Intestinal epithelium and autophagy: partners in gut homeostasis. Front Immunol 2013, 4:301.

50. Marselli L, Bugliani M, Suleiman M, Olimpico F, Masini M, Petrini M, Boggi U, Filipponi F, Syed F, Marchetti P: beta-cell inflammation in human type 2 diabetes and the role of autophagy. Diabetes Obes Metab 2013, 15(Suppl 3):130-136
51. Pan L, Li Y, Jia L, Qin Y, Qi G, Cheng J, Qi Y, Li H, Du J: Cathepsin S deficiency results in abnormal accumulation of autophagosomes in macrophages and enhances Ang II-induced cardiac inflammation. PLOS One 2012, 7:e35315.

52. Junkins RD, McCormick C, Lin TJ: The emerging potential of autophagy-based therapies in the treatment of cystic fibrosis lung infections. Autophagy 2014, 10:538-547.

53. Francois $A$, Terro $F$, Janet $T$, Bilan AR, Paccalin M, Page G: Involvement of interleukin-1beta in the autophagic process of microglia: relevance to Alzheimer's disease. J Neuroinflammation 2013, 10:151.

54. Schwab C, Klegeris A, McGeer PL: Inflammation in transgenic mouse models of neurodegenerative disorders. Biochim Biophys Acta 2010, 1802:889-902.

55. Sarkar S: Regulation of autophagy by mTOR-dependent and mTORindependent pathways: autophagy dysfunction in neurodegenerative diseases and therapeutic application of autophagy enhancers. Biochem Soc Trans 2013, 41:1103-1130.

56. Jewell $\mathrm{J}$, Russell RC, Guan KL: Amino acid signalling upstream of mTOR. Nat Rev Mol Cell Biol 2013, 14:133-139.

57. Laplante M, Sabatini DM: mTOR Signaling. Cold Spring Harb Perspect Biol 2012, 4

58. Inoki K, Guan KL: Complexity of the TOR signaling network. Trends Cell Biol 2006, 16:206-212

59. Gwinn DM, Shackelford DB, Egan DF, Mihaylova MM, Mery A, Vasquez DS, Turk BE, Shaw RJ: AMPK phosphorylation of raptor mediates a metabolic checkpoint. Mol Cell 2008, 30:214-226.

60. Avrahami L, Farfara D, Shaham-Kol M, Vassar R, Frenkel D, Eldar-Finkelman H: Inhibition of glycogen synthase kinase-3 ameliorates beta-amyloid pathology and restores lysosomal acidification and mammalian target of rapamycin activity in the Alzheimer disease mouse model: in vivo and in vitro studies. J Biol Chem 2013, 288:1295-1306.

61. Caccamo A, Magri A, Medina DX, Wisely EV, Lopez-Aranda MF, Silva AJ, Oddo S: mTOR regulates tau phosphorylation and degradation: implications for Alzheimer's disease and other tauopathies. Aging Cell 2013, 12:370-380.

62. Lafay-Chebassier C, Paccalin M, Page G, Barc-Pain S, Perault-Pochat MC, Gi R, Pradier L, Hugon J: mTOR/p70S6k signalling alteration by Abeta exposure as well as in APP-PS1 transgenic models and in patients with Alzheimer's disease. J Neurochem 2005, 94:215-225.

63. Caccamo A, Majumder S, Richardson A, Strong R, Oddo S: Molecular interplay between mammalian target of rapamycin (mTOR), amyloidbeta, and Tau: effects on cognitive impairments. J Biol Chem 2010, 285:13107-13120.

64. Damjanac M, Rioux Bilan A, Paccalin M, Pontcharraud R, Fauconneau B, Hugon J, Page G: Dissociation of Akt/PKB and ribosomal S6 kinase signaling markers in a transgenic mouse model of Alzheimer's disease. Neurobiol Dis 2008, 29:354-367.

65. Sanchez-Varo R, Trujillo-Estrada L, Sanchez-Mejias E, Torres M, Baglietto-Vargas D, Moreno-Gonzalez I, De Castro V, Jimenez S, Ruano D, Vizuete M, Davila JC, Garcia-Verdugo JM, Jimenez AJ, Vitorica J, Gutierrez A: Abnormal accumulation of autophagic vesicles correlates with axonal and synaptic pathology in young Alzheimer's mice hippocampus. Acta Neuropathol 2012, 123:53-70

66. Khandelwal PJ, Herman AM, Hoe HS, Rebeck GW, Moussa CE: Parkin mediates beclin-dependent autophagic clearance of defective mitochondria and ubiquitinated Abeta in AD models. Hum Mol Genet 2011, 20:2091-2102.

67. Mathews PM, Cataldo AM, Kao BH, Rudnicki AG, Qin X, Yang JL, Jiang $Y$, Picciano M, Hulette C, Lippa CF, Bird TD, Nochlin D, Walter J, Haass C, Levesque L, Fraser PE, Andreadis A, Nixon RA: Brain expression of presenilins in sporadic and early-onset, familial Alzheimer's disease. Mol Med 2000, 6:878-891.

68. Cataldo AM, Petanceska S, Terio NB, Peterhoff CM, Durham R, Mercken M, Mehta PD, Buxbaum J, Haroutunian V, Nixon RA: Abeta localization in abnormal endosomes: association with earliest Abeta elevations in AD and Down syndrome. Neurobiol Aging 2004, 25:1263-1272.

69. Adamec E, Mohan PS, Cataldo AM, Vonsattel JP, Nixon RA Up-regulation of the lysosomal system in experimental models of neuronal injury: implications for Alzheimer's disease. Neuroscience 2000, 100:663-675. 
70. Cogswell JP, Ward J, Taylor IA, Waters M, Shi Y, Cannon B, Kelnar K, Kemppainen J, Brown D, Chen C, Prinjha RK, Richardson JC, Saunders AM, Roses AD, Richards CA: Identification of miRNA changes in Alzheimer's disease brain and CSF yields putative biomarkers and insights into disease pathways. J Alzheimers Dis 2008, 14:27-41.

71. Lee JH, Yu WH, Kumar A, Lee S, Mohan PS, Peterhoff CM, Wolfe DM, Martinez-Vicente M, Massey AC, Sovak G, Uchiyama Y, Westaway D, Cuervo AM, Nixon RA: Lysosomal proteolysis and autophagy require presenilin 1 and are disrupted by Alzheimer-related PS1 mutations. Cell 2010, 141:1146-1158.

72. Wolfe DM, Lee JH, Kumar A, Lee S, Orenstein SJ, Nixon RA: Autophagy failure in Alzheimer's disease and the role of defective lysosomal acidification. Eur J Neurosci 2013, 37:1949-1961.

73. Rohn TT, Wirawan E, Brown RJ, Harris JR, Masliah E, Vandenabeele P: Depletion of Beclin-1 due to proteolytic cleavage by caspases in the Alzheimer's disease brain. Neurobiol Dis 2011, 43:68-78.

74. Luo S, Rubinsztein DC: Apoptosis blocks Beclin 1-dependent autophagosome synthesis: an effect rescued by Bcl-xL. Cell Death Differ 2010, 17:268-277.

75. Salminen A, Kaarniranta K, Kauppinen A: Beclin 1 interactome controls the crosstalk between apoptosis, autophagy and inflammasome activation: impact on the aging process. Ageing Res Rev 2013, 12:520-534

76. Korkmaz G, le Sage C, Tekirdag KA, Agami R, Gozuacik D: miR-376b controls starvation and mTOR inhibition-related autophagy by targeting ATG4C and BECN1. Autophagy 2012, 8:165-176.

77. Zou Z, Wu L, Ding H, Wang Y, Zhang Y, Chen X, Zhang CY, Zhang Q, Zen K: MicroRNA-30a sensitizes tumor cells to cis-platinum via suppressing beclin 1-mediated autophagy. J Biol Chem 2012, 287:4148-4156.

78. Jaeger PA, Pickford F, Sun CH, Lucin KM, Masliah E, Wyss-Coray T: Regulation of amyloid precursor protein processing by the Beclin 1 complex. PLoS One 2010, 5:e11102

79. Wang RC, Wei Y, An Z, Zou Z, Xiao G, Bhagat G, White M, Reichelt J, Levine $B$ : Akt-mediated regulation of autophagy and tumorigenesis through Beclin 1 phosphorylation. Science 2012, 338:956-959.

80. Lucin KM, O'Brien CE, Bieri G, Czirr E, Mosher Kl, Abbey RJ, Mastroeni DF, Rogers J, Spencer B, Masliah E, Wyss-Coray T: Microglial beclin 1 regulates retromer trafficking and phagocytosis and is impaired in Alzheimer's disease. Neuron 2013, 79:873-886.

81. Jounai N, Kobiyama K, Shiina M, Ogata K, Ishii KJ, Takeshita F: NLRP4 negatively regulates autophagic processes through an association with beclin1. J Immunol 2011, 186:1646-1655.

82. Dello Russo C, Lisi L, Tringali G, Navarra P: Involvement of mTOR kinase in cytokine-dependent microglial activation and cell proliferation. Biochem Pharmacol 2009, 78:1242-1251.

83. Weichhart T, Costantino G, Poglitsch M, Rosner M, Zeyda M, Stuhlmeier KM, Kolbe T, Stulnig TM, Horl WH, Hengstschlager M, Muller M, Saemann MD: The TSC-mTOR signaling pathway regulates the innate inflammatory response. Immunity 2008, 29:565-577.

84. Singer SJ, Tiernan R, Sullivan EJ: Interstitial pneumonitis associated with sirolimus therapy in renal-transplant recipients. N Engl J Med 2000, 343:1815-1816.

85. Thaunat O, Beaumont C, Chatenoud L, Lechaton S, Mamzer-Bruneel MF, Varet $\mathrm{B}$, Kreis $\mathrm{H}$, Morelon $\mathrm{E}$ : Anemia after late introduction of sirolimus may correlate with biochemical evidence of a chronic inflammatory state. Transplantation 2005, 80:1212-1219.

86. Kezic A, Becker JU, Thaiss F: The effect of mTOR-inhibition on NF-kappaB activity in kidney ischemia-reperfusion injury in mice. Transplant Proc 2013, 45:1708-1714.

87. Sardiello M, Ballabio A: Lysosomal enhancement: a CLEAR answer to cellular degradative needs. Cell Cycle 2009, 8:4021-4022.

88. Palmieri M, Impey S, Kang H, di Ronza A, Pelz C, Sardiello M, Ballabio A: Characterization of the CLEAR network reveals an integrated control of cellular clearance pathways. Hum Mol Genet 2011, 20:3852-3866.

89. Settembre C, De Cegli R, Mansueto G, Saha PK, Vetrini F, Visvikis O, Huynh T, Carissimo A, Palmer D, Klisch TJ, Wollenberg AC, Di Bernardo D, Chan L, Irazoqui JE, Ballabio A: TFEB controls cellular lipid metabolism through a starvation-induced autoregulatory loop. Nat Cell Biol 2013. 15:647-658.

90. Settembre C, Zoncu R, Medina DL, Vetrini F, Erdin S, Huynh T, Ferron M, Karsenty G, Vellard MC, Facchinetti V, Sabatini DM, Ballabio A: A lysosome-to-nucleus signalling mechanism senses and regulates the lysosome via mTOR and TFEB. EMBO J 2012, 31:1095-1108.
91. Zhu XC, Yu JT, Jiang T, Tan L: Autophagy modulation for Alzheimer's disease therapy. Mol Neurobiol 2013, 48:702-714.

92. Torres M, Jimenez S, Sanchez-Varo R, Navarro V, Trujillo-Estrada L, Sanchez-Mejias E, Carmona I, Davila JC, Vizuete M, Gutierrez A, Vitorica J: Defective lysosomal proteolysis and axonal transport are early pathogenic events that worsen with age leading to increased APP metabolism and synaptic Abeta in transgenic APP/PS1 hippocampus. Mol Neurodegener 2012, 7:59.

doi:10.1186/s12974-014-0139-x

Cite this article as: François et al:: Longitudinal follow-up of autophagy and inflammation in brain of APPswePS1dE9 transgenic mice. Journal of Neuroinflammation 2014 11:139.

\section{Submit your next manuscript to BioMed Central and take full advantage of:}

- Convenient online submission

- Thorough peer review

- No space constraints or color figure charges

- Immediate publication on acceptance

- Inclusion in PubMed, CAS, Scopus and Google Scholar

- Research which is freely available for redistribution

Submit your manuscript at www.biomedcentral.com/submit
C) Biomed Central 